\title{
STATISTICAL ANALYSIS OF NITROGEN IN THE SOIL OF CONSTRUCTED WETLAND WITH HORIZONTAL SUB-SURFACE FLOW
}

\author{
Anita JAKUBASZEK ${ }^{1,1}$, Magdalena WOJCIECH ${ }^{2}$ \\ ${ }^{1}$ University of Zielona Gora, Institute of Environmental Engineering, Poland \\ ${ }^{2}$ University of Zielona Góra, Faculty of Mathematics, Computer Science and \\ Econometrics, Department of Mathematical Statistics and Econometrics
}

\begin{abstract}
The removal of nitrogen compounds in constructed wetlands depends on various physical, chemical and biomechanical factors as well as on conditions of the environment. The paper presents the results of a statistical analysis of the depositing of nitrogen at HSSF (horizontal subsurface flow) construcred wetland. The results of the substrate showed that the highest contents of nitrogen existed in the surface soil layer up to $20 \mathrm{~cm}$ of the depth. Nitrogen accumulation decreased in the deposit with depth, and in the direction of the wastewater flow.
\end{abstract}

Keywords: wastewater treatment, constructed wetlands, nitrogen

\section{INTRODUCTION}

Wastewater treatment in hydrophyte systems is a result of the intensification of mechanical, chemical and biological processes that occur in a natural soilvegetable and water environment. The transformation and removal of nitrogen are accomplished by pathways including biological (i.e. ammonification, nitrification, denitrification, plant uptake, biomass assimilation, dissimilatory nitrate reduction), and physico-chemical routes (e.g. ammonia volatilization, and adsorption). Nitrogen removal routes also depend on microbiological

\footnotetext{
${ }^{1}$ Corresponding author: University of Zielona Gora, Institute of Environmental Engineering, ul. Szafrana 15, 65-246 Zielona Góra, Poland; e-mail: a.jakubaszek@iis.uz.zgora.pl, tel. +48683282396
} 
metabolism such as partial nitrification-denitrification, Anammox and Canon processes [8].

Nitrogen brought to a wastewater treatment plant together with wastewaters comes in an organic and non-organic form. A part of organic nitrogen is removed from wastewaters together with a suspension in a process of mechanical wastewater treatment. However, a greater part of organic nitrogen undergoes ammonification processes and enters wastewaters as an ammonium ion $\left(\mathrm{NH}_{4}^{+}\right)$[5].

$$
\text { Amino acids } \rightarrow \text { Imino acids } \rightarrow \text { Keto acids } \rightarrow \mathrm{NH}_{3}
$$

In a constructed wetland, this process decreases with depth, indicating that ammonification is faster in the upper zone of the wetlands where the condition is aerobic, and slower in the lower zone where the environment switches from facultative anaerobic to obligate anaerobic conditions [8].

The most important mechanisms responsible for the removal of nitrogen from hydrophyte systems are the processes of nitrification and denitrification.

Biological nitrification is a two-phase process in which nitrogen is oxidized to nitrites and then to nitrates.

The first phase takes place in the presence of Nitrosomonas bacteria for which ammonia nitrogen oxidation to nitrite is a source of energy:

$$
\mathrm{NH}_{4}^{+}+1.5 \mathrm{O}_{2} \Rightarrow \mathrm{NO}_{2}^{-}+2 \mathrm{H}^{+}+\mathrm{H}_{2} \mathrm{O}
$$

In the second stage of nitrification Nitrobacter bacteria enter. They derive the energy they need from nitrites:

$$
\mathrm{NO}_{2}^{-}+0.5 \mathrm{O}_{2} \Rightarrow \mathrm{NO}_{3}^{-}
$$

Reference books state that ammonia oxidation to nitrites comes in two stages [2, 7 , 9]. First, ammonia is transformed into hydroxylamine - $\mathrm{NH}_{2} \mathrm{OH}$ that occurs following the reaction:

$$
\mathrm{NH}_{4}^{+}+0.5 \mathrm{O}_{2}+2 \mathrm{e}^{-} \Rightarrow \mathrm{NH}_{2} \mathrm{OH}+\mathrm{H}^{+}
$$

Then hydroxylamine is oxidized to nitrite following the reaction:

$$
\mathrm{NH}_{2} \mathrm{OH}+\mathrm{H}_{2} \mathrm{O} \Rightarrow \mathrm{NO}_{2}^{-}+5 \mathrm{H}++4 \mathrm{e}^{-}
$$

The effectiveness of the nitrification process depends on temperature, $\mathrm{pH}$, alkalinity, presence of non-organic source of carbon as well as on the concentration of oxygen. An optimum temperature in which nitrifying bacteria grow most intensively is from $25^{\circ} \mathrm{C}$ to $30^{\circ} \mathrm{C}$. The nitrification process is also significantly affected by the $\mathrm{pH}$ of the environment, the optimum values of which fall within the range of 7.2 -9.0. The oxidation of one mole of ammonia 


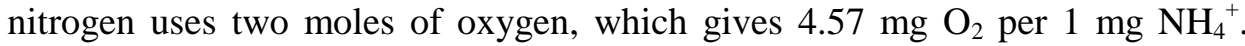
If biosynthesis is taken into account, then the demand for oxygen will be approximately $4.2 \mathrm{mg} \mathrm{O}_{2} / \mathrm{mg} \mathrm{NH}_{4}^{+}[2,7,9]$.

Denitrification is the process of nitrites or nitrates reduction to gaseous products. This process requires an anaerobic or anoxic environment.

The process of denirification is conditioned by the presence of oxidized forms of nitrogen and carbon compounds. Thus, the presence of $\mathrm{NO}_{3}{ }^{-}$ions depends on the process of nitrification. The speed of nitrification is also affected by the speed of $\mathrm{NO}_{3}{ }^{-}$ions migration from aerobic to anaerobic microzones. Carbon compounds in these ecosystems may come from organic substance contained in wastewaters or from remains of plants and organisms existing in the system and undergoing decomposition [6, 7]. According to Obarska-Pempkowiak et al. the denitrification of $1 \mathrm{~g}$ of nitrate nitrogen in the wastewater flowing through the constructed wetland requires bringing $0.7 \mathrm{~g}$ of carbon [5].

Apart from the required availability of carbon sources, the correct course of denitrification is also determined by such factors as temperature, $\mathrm{pH}$ as well as dissolved oxygen concentrations. A temperature of $20^{\circ} \mathrm{C}$ is the best for the correct course of the process. A higher temperature does not result in the process acceleration, whereas a lower temperature slows the process down. The optimum range of the $\mathrm{pH}$ reaction for the correct course of denitrification is 6.5-7.5. If the $\mathrm{pH}$ reaction goes down below 6.0 or up above 8.0 then denitrification quickly stops. Correct denitrification process also requires the adequate low oxygen concentration, which cannot exceed $0.5 \mathrm{~g} \mathrm{O}_{2} / \mathrm{m}^{3}$ [1]. Fig. 1 shows the major biological nitrogen removal routes in subsurface flow wetland systems [8].

The process that causes a temporary nitrogen retention in the hydrophyte ecosystem is its accumulation in the biomass as well as sorption processes that occur in the foundation. The ability of plants to retain nitrogen is limited by the speed of their growth as well as the content of such compounds in vegetable tissues.Plants derive nitrogen from the foundation first of all in a form of ammonia or nitrate ions. The intensity with which nitrogen is absorbed by plants depends on ion concentration in the soil as well as the $\mathrm{pH}$ of the environment. The intensity of absorption $\mathrm{NH}_{4}{ }^{+}$and $\mathrm{NO}_{3}{ }^{-}$increases along with the increase of soil acidification, whereas ammonia ions are absorbed more quickly from an alkaline solution [4]. A major problem for optimizing the classical nitrogen removal route is the necessity of maintaining alkalinity of wastewater, sequential aerobic-anaerobic conditions, and availability of organic carbon. Optimizing these conditions sometimes imposes process complexity [8]. 


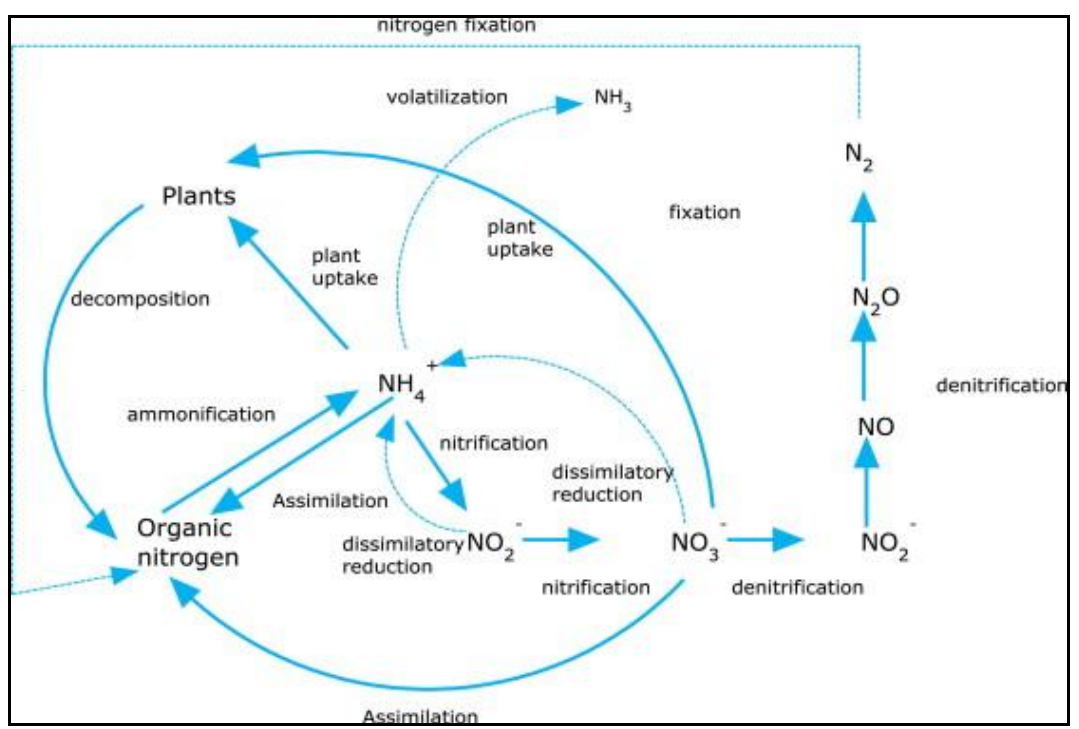

Fig. 1 Major classical nitrogen removal routes in subsurface flow wetlands [8]

The objective of the paper is to present the accumulation of total Kjeldahl nitrogen in the horizontal and vertical profile of the HSSF soil. The paper also contains the results of the analysis of the dependence between the deposition of TKN and the amount of the organic substance, total organic carbon and total phosphorus in deposit.

\section{MATERIAL AND METHODS}

The tests were carried out in a constructed wetland with horizontal sub-surface flow located in the Lubuski region in the town of Małaszyn. The facility was designed for $1300 \mathrm{PE}$ and commissioned in April 1993. The surface of the HSSF is $3800 \mathrm{~m}^{2}$ and it is planted with reeds (Phragmites australis). In accordance with design assumptions the root pond's bottom and its slopes are to be sealed using clay. The arrangement of sealing layers is the following:

- clay layer of thickness of $40 \mathrm{~cm}$,

- gravel and boulders layer of thickness of $40 \mathrm{~cm}$,

- soil and sand layer of thickness of $40 \mathrm{~cm}$.

After mechanical treatment in a 3-chamber sediment tank wastewater is directed to a distribution well located just before the deposit. Then, in a filter layer, the wastewater is distributed by means of perforated hole pipelines evenly across the whole width of the deposit. The root pond has a rectangular shape with the width of $40 \mathrm{~m}$ and the length of $95 \mathrm{~m}$. After the wastewater leaves the hydrophyte 
plot it goes through a collecting pipeline to a collecting well and then through a drainage ditch it reaches stabilization the ponds and finally the collector. The test material were taken during the period of one year, every six weeks. Samples was collected at the beginning of the HSSF bed, its middle part and at its end. Soil samples were taken at three depths: $0-20 \mathrm{~cm}, 20-40 \mathrm{~cm}$ and $40-60 \mathrm{~cm}$. The samples were collected according to PN-R-04031. Primary samples were collected from every selected area and then they were joined to make an overall sample. In order to obtain a laboratory sample, the overall sample was put on a plastic tray, mixed thoroughly and averaged and finally vegetable residues and other solid contaminants were removed. The material was then dried to obtain an air-dry state. To make the granulation standardized the dry mass was then mortar ground and sieved ( $2 \mathrm{~mm}$ diameter mesh screen). The total Kjeldahl nitrogen TKN in the soil samples was determined by means of a titrimetric method, titrating the distillate with a nominated solution of sodium base (after mineralization of the soil samples according to PN-91/R04014 in the sulfuric acid environment using a microwave mineralizer ErtecMagnum II and after distillation of ammonia in a strong alkaline environment in Vapodest 30 device by C.Gerhardt). Total phosphorus in the samples was determined by Komprath's colorimeric method (after mineralization). The content of organic matter was determined by the weight method, dry combustion in a muffle furnace at a temperature of $550^{\circ} \mathrm{C}$. The total organic carbon - using dry combustion in an environment of pure oxygen and a temperature of $900^{\circ} \mathrm{C}$ in the device TOC-V CSN with extra equipment SSM-5000A Shimadzu.

\section{RESULTS}

The decomposition of nitrogen contents in a deposit as well as the basic values of descriptive statistics depending on the place and depth of sampling are presented in the box plot graphs (Fig. 2).

The biggest changes concerning the contents of the TKN during the tests occurred in the surface layer $0-20 \mathrm{~cm}$ deep, especially in the deposit samples collected from the wastewaters entering the wastewater treatment plant. The comparison of arithmetic means of nitrogen contents leads to the conclusion that independently of the place of sample collection these values vary at each depth and the average nitrogen content in the deposit decreases along with the depth.

In order to find out whether these differences are statistically significant a comparison analysis, namely the variance analysis ANOVA was made for the average values of the tested samples [3]. A two-factor variance analysis was performed for the randomized block scheme, where the place of deposit sample 
collection was assumed as factor A (inlet, middle part, outlet) whereas the other factor, namely B was the depth of the sample collection.

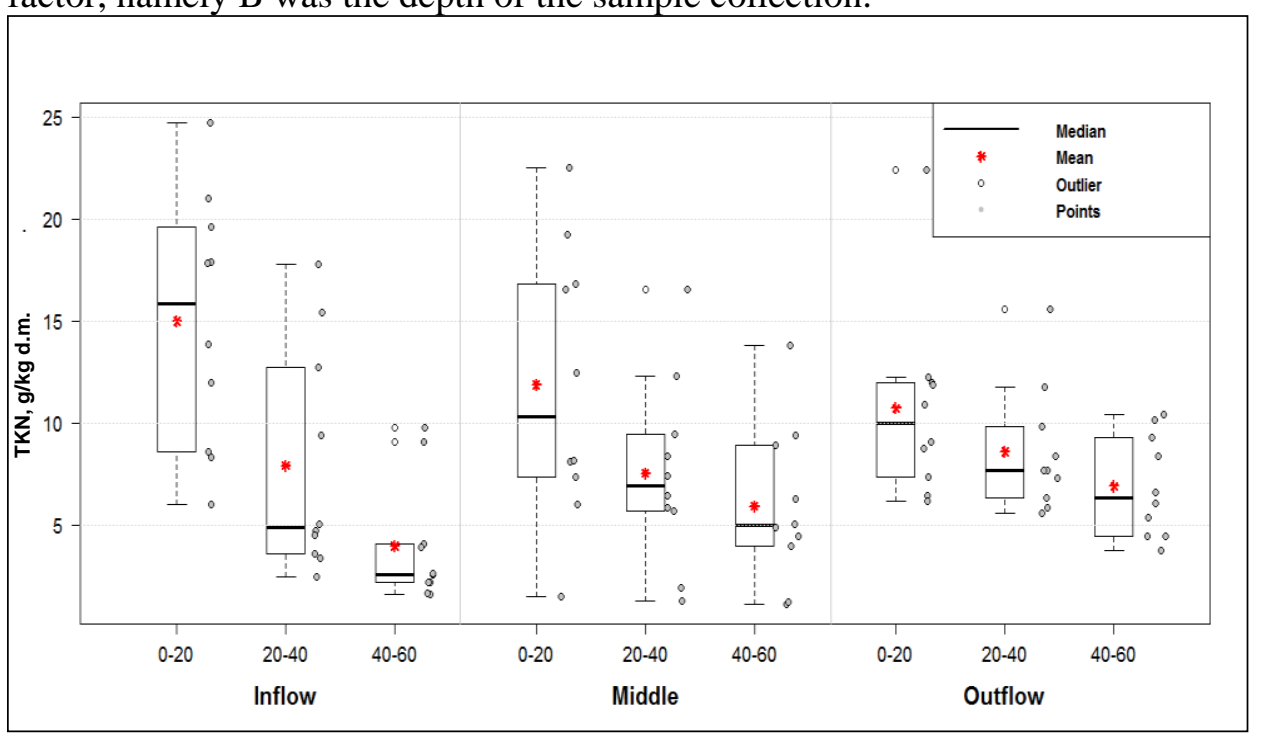

Fig. 2. Contents of TKN in the soil

It was assumed that the $\mathrm{p}$ value $<0.01$ indicates a statistically highly significant difference in the average nitrogen content in the samples under analysis. Before moving on to the variance analysis it was proved by means of the Shapiro-Wilk test that with a significance level of $\alpha=0.01$ there are no grounds for rejecting the hypothesis of the compliance of the rest distribution in the accepted model with the normal distribution $(\mathrm{W}=0.973$, $\mathrm{p}$ value $=0.08843$ ).

Table 1. Results of ANOVA variance analysis

\begin{tabular}{|l|c|c|c|c|c|}
\hline $\begin{array}{c}\text { Source of variation } \\
\text { of total nitrogen }\end{array}$ & $\begin{array}{c}\text { The sum of } \\
\text { squares of } \\
\text { deviations }\end{array}$ & $\begin{array}{c}\text { The } \\
\text { number of } \\
\text { degrees of } \\
\text { freedom }\end{array}$ & $\begin{array}{c}\text { Average of } \\
\text { squared } \\
\text { deviations }\end{array}$ & $\begin{array}{c}\text { The value } \\
\text { of statistics } \\
\mathrm{F}\end{array}$ & p value \\
\hline Factor A & 4.01 & 2 & 2.01 & 0.21 & 0.807093 \\
\hline Factor B & $743 ., 60$ & 2 & 371.80 & 39.84 & $2.247 * 10^{-12} * *$ \\
\hline Interaction AB & 143.70 & 4 & 35.92 & 3.85 & $0.006856^{* *}$ \\
\hline Mistake & 672.00 & 72 & 9.33 & - & - \\
** very important dependence $(p<0.01)$ & * important dependence $(p<0.05)$ \\
\hline
\end{tabular}

The variance analysis proved that the place of deposit sample collection did not differentiate significantly the average total Kjeldahl nitrogen contents in the deposit $(\mathrm{F}=0.215, \mathrm{p}$ value $=0.807)($ table 1$)$. On the other hand, the average 
total nitrogen content in the collected samples depended significantly on the depth of their collection $\left(\mathrm{F}=39.835\right.$, $\mathrm{p}$ value $\left.=2.247 * 10^{-12}\right)$. The effect of the interaction between the depth and the place of sample collection on the content of nitrogen was also recognized as highly significant $(\mathrm{F}=3.849$, $\mathrm{p}$ value $=$ 0.0069).

In order to check what levels of the factors under analysis significantly differentiate the contents of nitrogen in the deposit the Tukey method test of repeated comparisons of differences between pairs of average nitrogen contents for particular B factor levels and the interaction between the factor A and B was carried out (fig. 3).

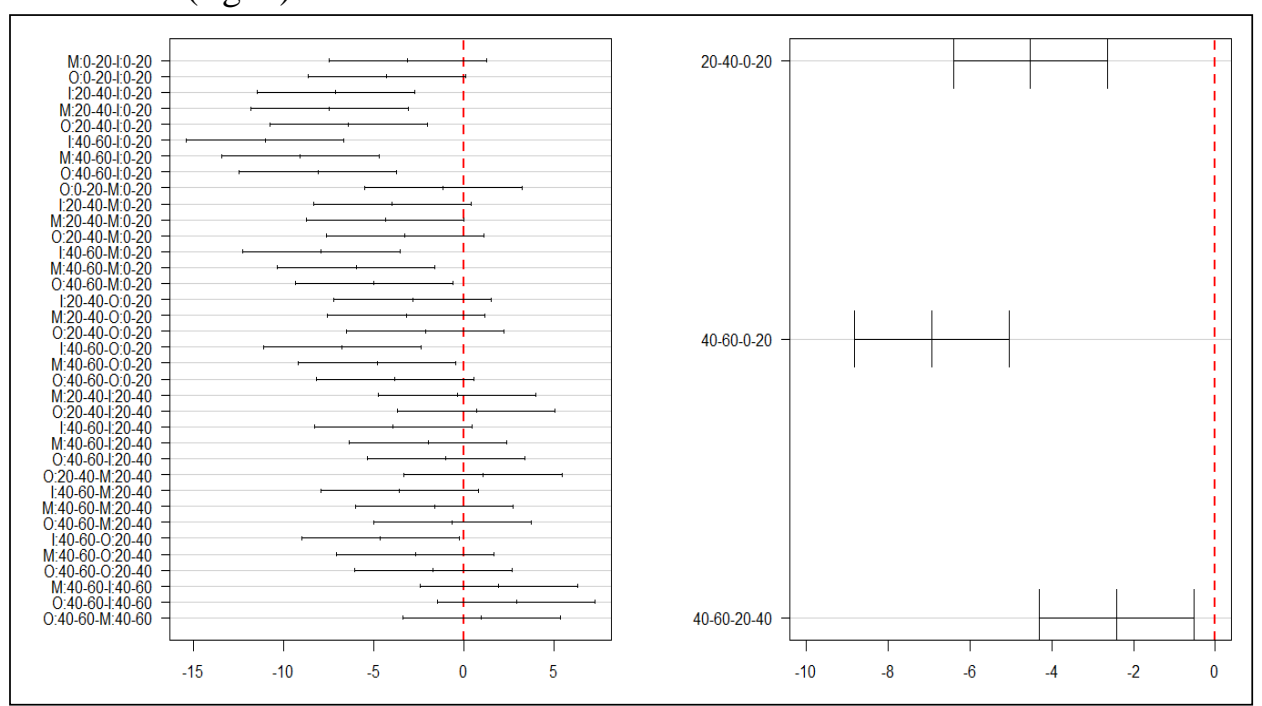

Fig. 3. Graphs of $95 \%$ confidence intervals for the differences in the average levels of

TKN (I - inflow, $\mathrm{M}$ - middle, O - outflow)

The analysis proved that statistically significant differences $(\mathrm{p}<0.05)$ between the average content of total Kjeldahl nitrogen in the deposit samples were for each pair of the depth: 0-20 and 20-40; 0-20 and 40-60; 20-40 and 40-60 cm (the smallest significant difference was $\left.\mathrm{NIR}_{\mathrm{B}}=1.89 \mathrm{gN} / \mathrm{kg} \mathrm{d} . \mathrm{m}\right)$. Where the highest absolute difference between the averages was for the nitrogen contained in the samples collected at a depth of $0-20 \mathrm{~cm}$ and $40-60 \mathrm{~cm}$ and reached $6.93 \mathrm{~g} / \mathrm{kg}$ d.m. Furthermore, taking into account the sample collection place the test proved, that the most significant difference in nitrogen contents from these depths occurred where the deposit began (the absolute difference was $11.02 \mathrm{~g} . \mathrm{kg}$ d.m. whereas $\mathrm{NIR}_{\mathrm{B} . \mathrm{A}}=3.27 \mathrm{gN} / \mathrm{kg}$ d.m.). Big and statistically significant differences in the average nitrogen content measurements were also observed in the inlet at the $0-20 \mathrm{~cm}$ layer and its accumulation was in the middle as well as 
at the end of the plot at a depth of 40-60 $\mathrm{cm}$ (the absolute differences were 9.08 and $8.09 \mathrm{~g} / \mathrm{kg} \mathrm{d.m}$. respectively). Statistically significant differences $(\mathrm{p}<0.05)$ in the average nitrogen deposit content also occurred between the inlet, in the 0.20 $\mathrm{cm}$ layer, and its accumulation in the next layer of $20-40 \mathrm{~cm}$ in each place of the collection (inlet, the middle part and outlet).

Research carried out by Vohla et al. has also shown the accumulation of N, P and $\mathrm{C}$ in the soil of the Kodijärve HSSF sand filter, a decreasing trend towards the outlet zone [10].

The soil deposit samples were also analyzed for the dependence between the TKN and, among other things, the amount of total organic carbon and total phosphorus in the organic matter deposit (fig. 4). In order to make a quantitative analysis of the dependence power there were correlation coefficients determined for each pair of variables. Earlier, the Shapiro-Wilk test performed showed that there was no accordance between every variable and the normal distribution for $\alpha=0.01$. Thus, the Spearman correlation coefficient $\left(r_{S}\right)$ was determined in the interdependence analysis as well as the $\mathrm{p}$ value following the Spearman rank correlation test. The analyses made indicated the strongest positive monotonic correlation between the TKN and organic substance $\left(\mathrm{r}_{\mathrm{S}}=0.949, \mathrm{p}\right.$ value $<2.2 * 10$ $\left.{ }^{16}\right)$ and the total organic carbon $\left(r_{S}=0.948, p\right.$ value $\left.<2.2 * 10^{-16}\right)$. They also proved a close monotonic relation between the TKN content and total phosphorus in the wastewater treatment plant deposit. This dependence was confirmed by the correlation coefficient of $\mathrm{r}_{\mathrm{S}}=0.80$ and $\mathrm{p}$ value $<2.2 * 10^{-16}$.

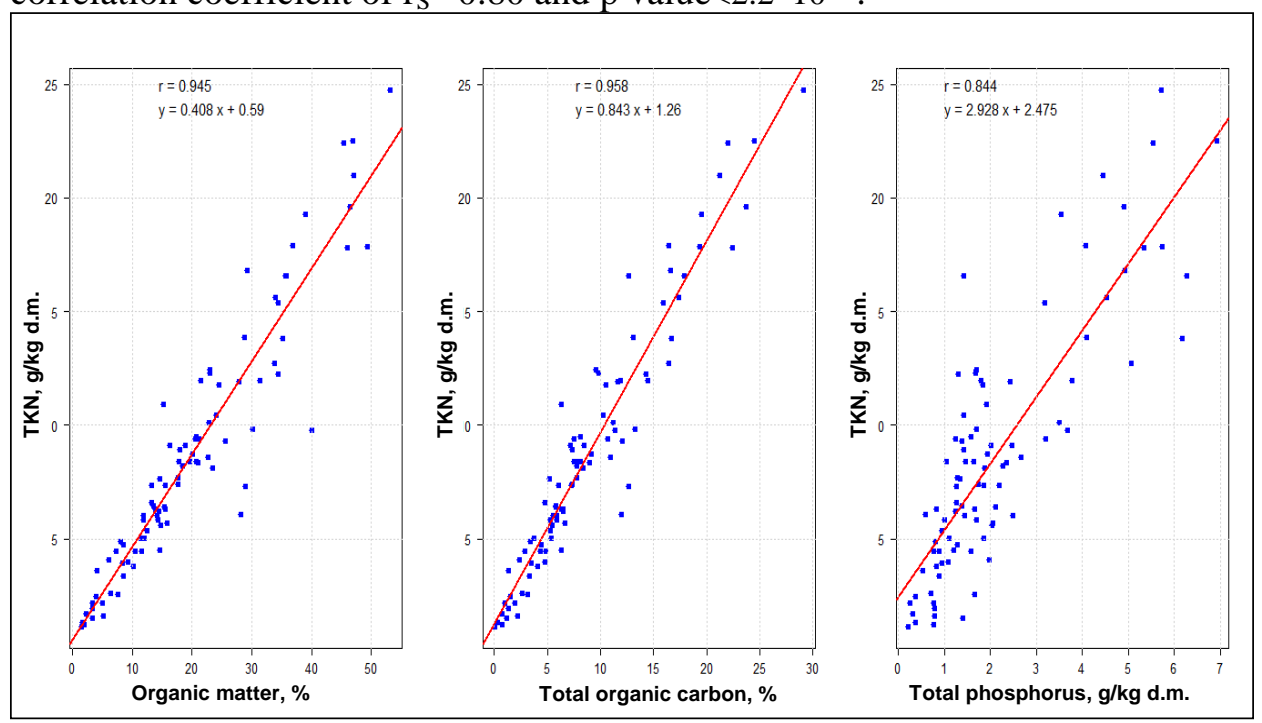

Fig. 4. Regression lines for the pairs of variables in the deposit 
Furthermore, the correlation graphs for the above pairs of variables (fig. 4) can indicate their linear dependence. The regression line equation (least squares) leads to the conclusion, that an increase in the organic carbon content in the deposit by $1 \%$ will result in an increase in the TKN content by $0.84 \mathrm{~g} / \mathrm{kg}$ d.m on average (model determination coefficient $\mathrm{R}^{2}=0.92$ ). A bigger increase of the nitrogen content in the deposit, by $2.93 \mathrm{~g} / \mathrm{kg} \mathrm{d.m}$. on average, can be expected along with an increase of the total phosphorus content by 1 gram of a $\mathrm{kg}$ of dry mass (at the determination coefficient of $\mathrm{R}^{2}=0.71$ ).

Furthermore, the interdependence between the nitrogen content and the total organic carbon was also evaluated taking into account both the place as well as the depth of the deposit sample collection. The results of the analysis are shown in figure 5 including the determined Pearson correlation coefficients (r). The correlation analyses of the total nitrogen in the deposit and the total organic carbon showed their very strong linear dependence at all the depth levels in the beginning of the plot and its middle part as well as in the surface layer at the end of the constructed wetland. However, at depths of $20-40 \mathrm{~cm}$ and $40-60 \mathrm{~cm}$ this dependence was weaker.

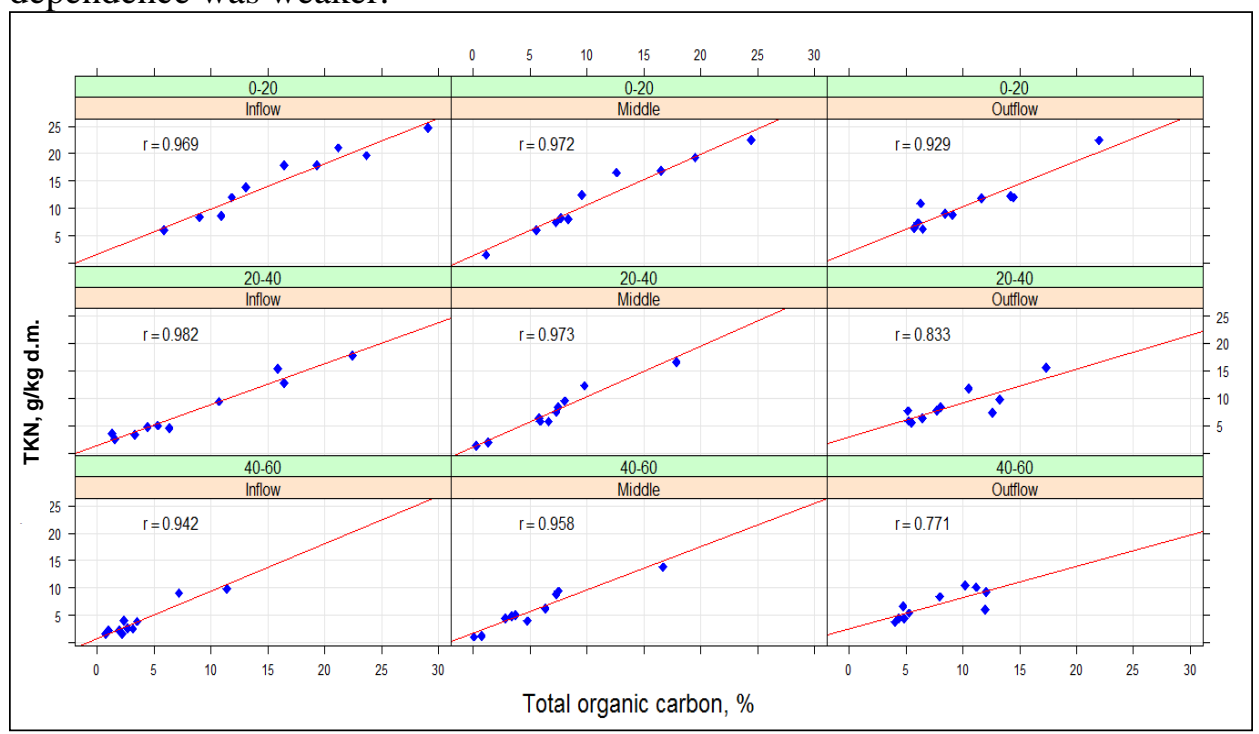

Fig. 5. Correlation between the TKN content and organic carbon content at particular deposit depths including the place of sample collection

\section{CONCLUSIONS}

The following conclusions can be drawn from the investigations carried out: 
- the highest soil layer of the constructed wetland up to $20 \mathrm{~cm}$ of its depth has the biggest accumulation of TKN,

- the content of nitrogen in the soil decreases with increasing depth,

- the variance analysis proved that the place of deposit sample collection did not differentiate significantly the average TKN contents in the deposit,

- the variance analysis proved that the average TKN content in the collected samples depended significantly on the depth of their collection,

- the average cumulative accumulation demonstrated a decreasing trend towards the outlet zone for all cases.

\section{ADDITIONAL INFORMATION}

The tests were carried out with the financial support from the Ministry of Science and Higher Education under the research promoter's project N N523 558538 .

\section{REFERENCES}

1. Bernacka J., Kurbiel J., Pawłowska L.: Usuwanie zwiazków biogennych ze ścieków miejskich, podstawy teoretyczne, stan badań, zastosowania w kraju, Instytut Ochrony Środowiska, Warszawa, 1992.

2. Klimiuk E., Łebkowska M.: Biotechnologia $w$ ochronie środowiska, Wydawnictwo Naukowe PWN, Warszawa, 2008.

3. Koronacki J., Mielniczuk J.: Statystyka dla studentów kierunków technicznych $i$ przyrodniczych, Wydawnictwo Naukowo-Techniczne, Warszawa, 2001.

4. Kubik-Dobosz G., Kłobus G., Burzyński M.: Praktikum z Fizjologii roślin. Gospodarka azotowa, fosforowa $i$ wptyw metali ciężich, Wydawnictwo Uniwersytetu Wrocławskiego, 1994.

5. Obarska-Pempkowiak H., Gajewska M., Wojciechowska E.: Hydrofitowe oczyszczanie wód i ścieków, Wydawnictwo Naukowe PWN, Warszawa, 2010.

6. Randall C., Barnard J., Stensel D.: Design and retrofit of wastewater treatment plants for biological nutrient removal, Technomic Publishing Co.Inc. 5, Lancaster-Basel, 1992.

7. Sadecka Z.: Podstawy biologicznego oczyszczania ścieków, Wydawnictwo Seidel Przywecki Sp. z o.o., Warszawa, 2010.

8. Saeed T., Sun G.: A review on nitrogen and organics removal mechanisms in subsurface flow constructed wetlands: Dependency on environmental 
parameters, operating conditions and supporting media, Journal of Environmental Management, 112 (2012) 429-448.

9. Schlegel H.: Mikrobiologia ogólna, Wydawnictwo Naukowe PWN, Warszawa, 2004.

10. Vohla C., Alas R., Nurk K., Baatz S., Mander Ü.: Dynamics of phosphorus, nitrogen and carbon removal in horizontal subsurface flow constructed wetland, Science of The Total Environment, 380 (2007) 66-74.

\section{ANALIZA STATYSTYCZNA AZOTU W ZŁOŻU OCZYSZCZALNI HYDROFITOWEJ Z POZIOMYM PODPOWIERZCHNIOWYM PRZEPŁYWEM ŚCIEKÓW}

\section{Streszczenie}

Usuwanie związków azotu w oczyszczalniach hydrofitowych uzależnione jest od wielu czynników fizyczno-chemicznych i biochemicznych oraz warunków środowiskowych. $\mathrm{W}$ artykule przedstawiono opacowanie statystyczne zawartości azotu ogólnego Kjeldahla w złożu hydrofitowym oczyszczalni. Wyniki badań materiału filtracyjnego wykazały, że największą zawartością azotu charakteryzowała się powierzchniowa warstwa gruntu do $20 \mathrm{~cm}$ głębokości. Kumulacja azotu malała wraz z penetracją w głąb złoża oraz w kierunku odpływu ścieków z oczyszczalni.

Słowa kluczowe: oczyszczanie ścieków, oczyszczalnie hydrofitowe, azot

Editor received the manuscript: $\quad 03.04 .2013$ 